\title{
Recovery of a dystrophic Red Latosol (Oxisol) and pasture as a function of gypsum in the Cerrado biome
}

\author{
Clarice Backes ${ }^{1 *}$, Alessandro José Marques Santos ${ }^{1}$, Lucas Matheus Rodrigues ${ }^{1}$, Arthur \\ Gabriel Teodoro', Adriana Aparecida Ribon², Roberto Lyra Villas Bôas ${ }^{3}$, Lorena Marques \\ Pereira', Yago Magalhães Franco ${ }^{1}$
}

\author{
${ }^{1}$ Universidade Estadual de Goiás, São Luís de Montes Belos, GO, Brazil. \\ ${ }^{2}$ Universidade Estadual de Goiás, Palmeiras de Goiás, GO, Brazil. \\ ${ }^{3}$ Universidade Estadual Paulista "Júlio de Mesquita Filho", Faculdade de Ciências Agronômicas, Botucatu, SP, Brazil.
}

\begin{abstract}
This study was conducted to evaluate the chemical effects of gypsum on the soil and on the recovery of a pasture established with palisade grass (Urochloa brizantha) in a Cerrado biome region. A randomized block experimental design with six treatments and four replications was adopted. Treatments consisted of five levels of gypsum $(0,450,900$, 1800 , and $3600 \mathrm{~kg} \mathrm{ha}^{-1}$ ) plus an unmanaged control treatment (without gypsum or additional chemical fertilizers). The gypsum treatments received addition of fertilizer (200 and $40 \mathrm{~kg} \mathrm{ha}^{-1}$ of $\mathrm{N}$ and P respectively). The soil treatment started in October 2012. The application of gypsum provided an increase in plant height, number of tillers, and dry matter of the shoots of palisade grass. Gypsum combined with chemical fertilizers provided an increase in productivity compared with chemical fertilizers alone. The use of gypsum improved the chemical characteristics of the soil, increasing calcium and sulfur in the deeper layers, consequently, providing greater development of the palisade grass root system. High gypsum levels impaired the development of the root system, especially in the 0.20-0.40 m layer. Gypsum provides recovery of soil and degraded pastures.
\end{abstract}

Key Words: degraded pasture, palisade grass, soil conditioner, Urochloa brizantha

\section{Introduction}

Pasture degradation is considered one of the major obstacles faced by the Brazilian cattle industry, because this activity is basically held on pastures, which directly affects the sustainability of the production system. Degradation can be caused by several factors, including the wrong choice of grass species, poor initial arrangement in the field, inadequate pasture management, overgrazing, and loss of soil fertility due to a lack of maintenance fertilization (Peron and Evangelista, 2004).

Muller et al. (2001) found that, in degraded areas, reduced forage production is accompanied by a decreased number of roots in the soil profile that lead to a concentration of roots near the surface, which makes plants more

Received: July 5, 2016

Accepted: January 28, 2017

*Corresponding author: clarice.backes@ueg.br

http://dx.doi.org/10.1590/S1806-92902017000400003

How to cite: Backes, C.; Santos, A. J. M.; Rodrigues, L. M.; Teodoro, A. G.; Ribon, A. A.; Villas Bôas, R. L.; Pereira, L. M. and Franco, Y. M. 2017. Recovery of a dystrophic Red Latosol (Oxisol) and pasture as a function of gypsum in the Cerrado biome. Revista Brasileira de Zootecnia 46(4):286-295

Copyright (C) 2017 Sociedade Brasileira de Zootecnia. This is an Open Access article distributed under the terms of the Creative Commons Attribution License (http://creativecommons.org/licenses/by/4.0/), which permits unrestricted use, distribution, and reproduction in any medium, provided the original work is properly cited. susceptible to water deficits and limits their ability to absorb nutrients in subsurface layers. According to Bonfim-Silva and Monteiro (2010), both the productivity and longevity of the pasture rely on a well-developed root system.

The Cerrado (Brazilian savannah) biome is an environment where low natural fertility and climatic conditions with rainfall seasonality are common occurrences. When associated with a lower water retention capacity, these factors may restrict the crop production process, requiring proper management (Crusciol et al., 2016). These soils generally have a low $\mathrm{pH}$, low exchangeable calcium and magnesium contents, relatively high levels of exchangeable aluminum, and low base saturation (Monteiro, 2010). As stated by Pimenta et al. (2010), proper management of pastures and fertilization practices are efficient in maintaining the chemical conditions of the soil, as they generate proper conditions for plant growth, establishing a balance in the soil-plant-animal interface, making it a sustainable system.

The improvement of soil conditions beneath the surface layers can increase forage productivity because the calcium deficiency, which may or may not be associated with aluminum toxicity, does not occur only in the topsoil. Thus, the use of gypsum, especially in established pastures, is recommended due to its greater solubility and mobility in the soil profile when compared with limestone; it provides 
an increase in calcium supply and reduces aluminum toxicity in the subsoil (Belchior et al., 2010), in addition to providing sulfur to plants (Vitti et al., 2008). According to Rodrigues et al. (2004), sulfur deficiency has a direct effect on the development and, consequently, on the nutritional value of forage plants.

Positive results from application of gypsum were obtained by Custódio et al. (2005), who reported an increased dry matter yield and height in Tanzania grass (Panicum maximum Jacq. Cv. Tanzania-1). Soratto and Crusciol (2008) obtained a $15.6 \%$ increase in dry matter yield from oat by applying gypsum in a no-tillage system compared with plants that did not receive the product. Mesquita et al. (2004) found that signal grass (Uroclhoa decumbens) showed an increase in number of tillers and in height during the second year of evaluation and that the substitution of limestone for gypsum improved the root medium, with translocation of $\mathrm{Ca}^{2+}, \mathrm{Mg}^{2+}$, and $\mathrm{S}^{-\mathrm{SO}_{4}}{ }^{2-}$ to the $0.15-0.30 \mathrm{~m}$ deep layer.

This study was conducted to evaluate the chemical effects of gypsum on the soil characteristics and on the recovery of pastures established with palisade grass (Urochloa brizantha) in the Cerrado region.

\section{Material and Methods}

The experiment was conducted on a palisade grass (Urochloa brizantha) pasture field established in São Luís de Montes Belos, GO, Brazil. The experimental area is located at $579 \mathrm{~m}$ asl, $16^{\circ} 31^{\prime} 30^{\prime \prime} \mathrm{S}$, and $50^{\circ} 22^{\prime} 20^{\prime \prime} \mathrm{W}$. The pasture had been cultivated for over 10 years with no adequate management practices, especially replenishment of the extracted nutrients, displaying visible signs of soil degradation.

The forage evaluation period was two years, from October 2012 to September 2014. During this period, the average, maximum, and minimum temperatures and precipitation were recorded (Figure 1).

The soil of the experimental area was classified as a dystrophic Red Latosol (Oxisol) of clayey texture (Embrapa, 2013; Red Ferralsol by WRB, 2015). At the beginning of the experiment, the soil showed the following chemical properties in the $0.00-0.20 \mathrm{~m}$ layer: $\mathrm{pH}\left(\mathrm{CaCl}_{2}\right), 5.2$; organic matter, $39 \mathrm{~g} \mathrm{dm}^{-3} ; \mathrm{P}$ (resin), $6 \mathrm{mg} \mathrm{dm}{ }^{-3} ; \mathrm{H}^{+}+\mathrm{Al}^{+3}, \mathrm{Al}^{3+}$, $\mathrm{K}, \mathrm{Ca}$, and $\mathrm{Mg}, 28,0,3.7,23$, and $8 \mathrm{mmol}_{\mathrm{c}} \mathrm{dm}^{-3}$, respectively; base saturation, $55 \%$; and $\mathrm{S}, 6 \mathrm{mg} \mathrm{dm}^{-3}$. In the $0.20-0.40 \mathrm{~m}$ layer, the following results were observed: $\mathrm{pH}\left(\mathrm{CaCl}_{2}\right), 5.2$; organic matter , $29 \mathrm{~g} \mathrm{dm}^{-3} ; \mathrm{P}$ (resin) $-5 \mathrm{mg} \mathrm{dm}{ }^{-3} ; \mathrm{H}^{+}+\mathrm{Al}^{+3}, \mathrm{Al}^{3+}$, $\mathrm{K}, \mathrm{Ca}$, and $\mathrm{Mg}, 32,0,2.6,11$, and $4 \mathrm{mmol}_{\mathrm{c}} \mathrm{dm}^{-3}$, respectively; base saturation, $50 \%$; and $\mathrm{S}, 4 \mathrm{mg} \mathrm{dm}^{-3}$.
To define the gypsum level, the soil was sampled in the 0.20-0.40 m layer to determine its chemical characteristics and its clay content, which resulted in $360 \mathrm{~g} \mathrm{~kg}^{-1}$. The used formula was GD $\left(\mathrm{kg} \mathrm{ha}^{-1}\right)=5.0 \times$ clay $\left(\mathrm{g} \mathrm{kg}^{-1}\right)$, in which $\mathrm{GD}=$ gypsum dose, according to Sousa and Lobato (2004).

A randomized block experimental design was adopted, with six treatments and four replications each. Treatments consisted of application of five levels of gypsum $(0,450,900$, 1800 , and $3600 \mathrm{~kg} \mathrm{ha}^{-1}$ corresponding to $0,25,50,100$, and $200 \%$ of the recommended percentages) plus one unmanaged control treatment. The gypsum treatments received additional fertilizer application of 200 and $40 \mathrm{~kg} \mathrm{ha}^{-1}$ year $^{-1}$ of $\mathrm{N}$ and $\mathrm{P}$ respectively, as recommended by Vilela et al. (2004). The gypsum was acquired from a phosphoric acid industry located in the city of Catalão, $\mathrm{GO}$, Brazil; its $\mathrm{Ca}, \mathrm{S}, \mathrm{P}_{2} \mathrm{O}_{5}$, and moisture contents were $180,150,7.5 \mathrm{~g} \mathrm{~kg}^{-1}$ and $17 \%$, respectively.

On October 16, 2012, the forage was harvested at an approximate height of 0.15 to $0.20 \mathrm{~m}$ and $10-\mathrm{m}^{2}$ plots were delimited. The gypsum was applied manually to the surface on October 30, 2012 according to the previously described treatments. On November 17, 2012, with the exception of the unmanaged control treatment, P fertilizer was applied, considering the recommended level for both the crop and soil analysis, with triple superphosphate ( $20 \%$ of P). Nitrogen fertilization was split into three applications, after harvesting the forage on the following dates: November 17 , 2012; January 21, 2013; and March 15, 2013, using urea.

Based on the initial soil analysis, liming was not necessary because the saturation by alkaline compounds exceeded the recommended values. Soil correction with potassium was also not necessary.

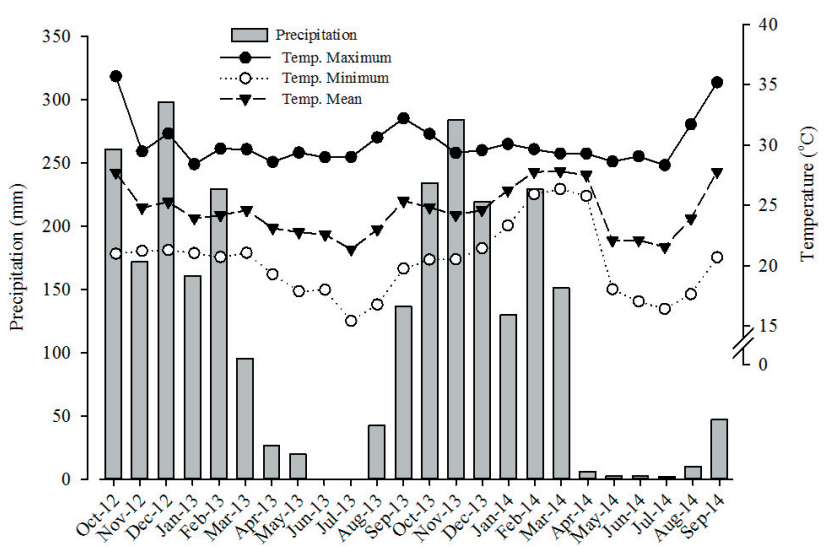

Figure 1 - Mean, maximum, and minimum temperatures and precipitation during the experiment (October 2012 to September 2014). 
For the second year of evaluation, the residual effect of gypsum was evaluated. Based on the mean $\mathrm{P}$ and $\mathrm{K}$ contents found in the soil $\left(\mathrm{P}=5.1 \mathrm{mg} \mathrm{dm}^{-3} ; \mathrm{K}=0.7 \mathrm{mmol}_{\mathrm{c}} \mathrm{dm}^{-3}\right)$, phosphate and potassium fertilization was applied at the respective $\mathrm{P}$ and $\mathrm{K}$ levels of 30 and $33 \mathrm{~kg} \mathrm{ha}^{-1}$, on October 24,2013 . The sources used were triple superphosphate and potassium chloride. Soon after the grass was lowered, nitrogen fertilization (at the dose of $200 \mathrm{~kg} \mathrm{ha}^{-1}$ (urea)) was also split into three dates: October 24, 2013; December 13, 2013; and February 27, 2014. The unmanaged control treatment did not receive any fertilizer application.

In both the first and second years of the experiment, the forage was harvested four times - three times during the rainy season and once in the dry season. The evaluation periods for the structural and productive traits were distributed as follows: for the first year - January, March, and April (rainy season) and September (dry season); for the second year - December, February, and April (rainy season) and September (dry season).

Plant height was determined before each forage harvest (lowering), using a wooden meter stick. This variable was measured from the soil level to the tallest leaf, in five points of the usable area of each plot.

To determine forage yield, forage was collected with a $1.0 \times 0.30 \mathrm{~m}$ iron frame and cut with steel shears at a height of $0.20 \mathrm{~m}$ from the soil. Thereafter, the material was weighed (fresh weight) and only one sample was packed in paper bags to be dried in a forced-air oven for $72 \mathrm{~h}$ at $65^{\circ} \mathrm{C}$. After that period, the sample dry weight was determined.

The tiller density was obtained with a $0.25 \times 0.25 \mathrm{~m}$ metal square frame. The number of tillers per square meter was calculated based on the number of tillers present within the area of each frame. These frames were placed in representative points of the pasture condition (average height) at the moment of sampling.

To evaluate the root systems, a hand auger with $0.05 \mathrm{~m}$ in diameter was used to obtain samples of roots from the $0.00-0.20$ and $0.20-0.40 \mathrm{~m}$ soil layers. Soil was separated from the roots by washing. Immediately afterwards, the plant material was dried in an oven to determine its dry mass.

Soil sampling for chemical analysis was carried out twice yearly (May 2013 and April 2014), using a soil probe at depths going from 0.00 to 0.20 and 0.20 to $0.40 \mathrm{~m}$ to determine the $\mathrm{pH}$, organic carbon, cation-exchange capacity, base saturation, and contents of $\mathrm{P}, \mathrm{K}, \mathrm{Ca}, \mathrm{Mg}, \mathrm{S}$, $\mathrm{Al}$, and $\mathrm{H}+\mathrm{Al}$, according to the methodology proposed by Raij et al. (2001).

Prior to statistical analysis, the data were tested for normality (Shapiro-Wilk) and homoscedasticity (BoxCox). The obtained results were subjected to analysis of variance to check for existing differences among treatments. Regression equations were obtained based on gypsum levels and contrast analysis between unmanaged control and the other treatments was performed. Data were analyzed using SAS (Statistical Analysis Sistem, University Edition).

\section{Results and Discussion}

During the first cycle, there was an influence of gypsum levels on plant height in the four evaluated seasons $(\mathrm{P}<0.01)$. The height values fitted the applied doses quadratically (Figure 2). According to the equations, the estimated gypsum levels of 1957, 2250, 1975, and $1833 \mathrm{~kg} \mathrm{ha}^{-1}$ provided the maximum heights of $132,44,36$, and $17 \mathrm{~cm}$ respectively.

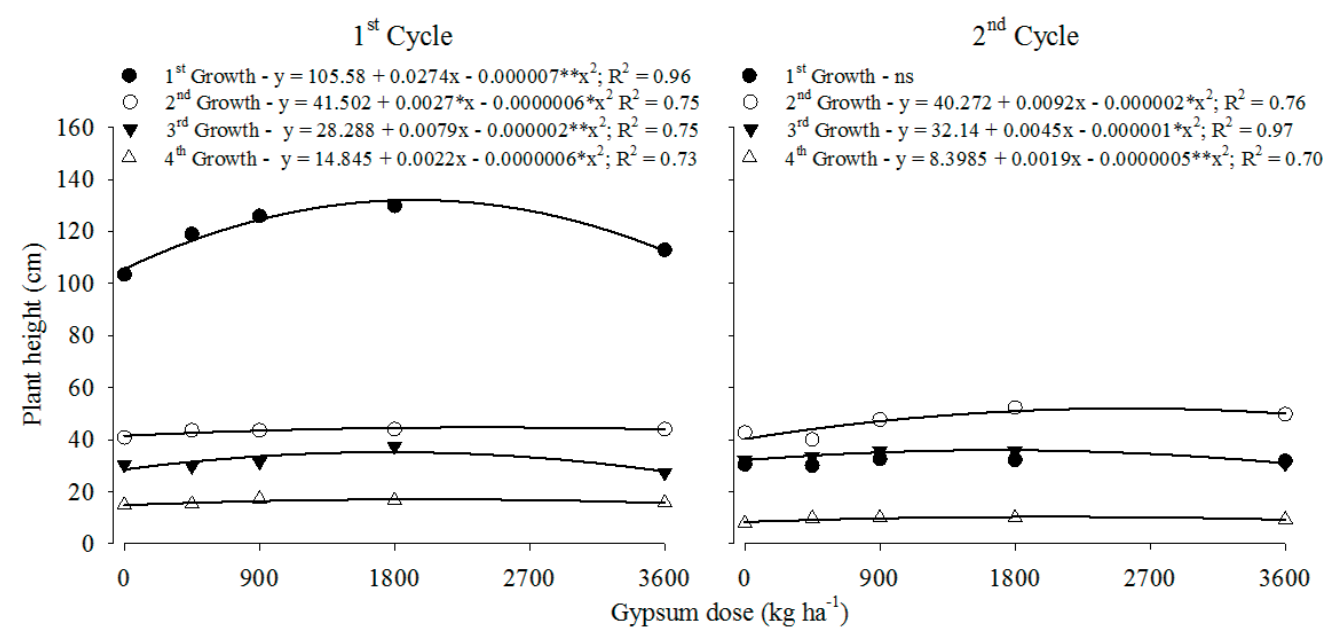

Figure 2 - Height of Urochloa brizantha subjected to levels of agricultural gypsum (1st, 2nd, and 3rd growth stages [rainy season] and 4th growth stage [dry season]) during the first and second cycles. 
In the second cycle, the influence of gypsum levels on plant height was not observed only in the first growth. At the other evaluated periods, there was a quadratic fit and, according to the equations, the estimated gypsum levels of 2300, 2250, and $1900 \mathrm{~kg}$ provided the maximum values (Figure 2). Oliveira et al. (2009) tested the effect of gypsum as calcium source in the development of intercropped and monocropped grasses and found, in monocropped $U$. brizantha, a $297 \%$ increase in plant height with the limestone source and $328 \%$ with the gypsum source compared with the control.

In the comparison between the group of fertilized treatments and control (no gypsum or fertilization), significant contrasts were obtained for all evaluated periods (Table 1). Mean values for plant height in the additional treatments were statistically lower than those of fertilized treatments. This finding reveals the response of the forage plant to the applied nutrients.

For the shoot dry matter of palisade grass (U. brizantha), quadratic fits occurred depending on the gypsum levels evaluated in the two cycles. In the first cycle, the maximum accumulations $\left(5681,2016\right.$, and $7559 \mathrm{~kg} \mathrm{ha}^{-1}$ ) were obtained with the estimated gypsum levels of 2004, 1959, and $2474 \mathrm{~kg} \mathrm{ha}^{-1}$ in the first, second, and third harvests, respectively, in the rainy season, and $2886 \mathrm{~kg} \mathrm{ha}^{-1}$ dry matter with the estimated gypsum level of $1779 \mathrm{~kg} \mathrm{ha}^{-1}$ during the dry season. In the second cycle, according to the equations, dry matter yields of $3892,4664,6425$, and $2996 \mathrm{~kg} \mathrm{ha}^{-1}$ were obtained at the estimated levels of 2272, 2572, 2019, and $2804 \mathrm{~kg} \mathrm{ha}^{-1}$ for the first, second, third, and fourth harvests, respectively (Figure 3).

The increased forage productivity obtained with the application of gypsum has been proved by some authors.
Custódio et al. (2005) studied the application of gypsum levels in Tanzania grass cultivated in a Dark Red Latosol, in which productivity increased together with the increase in gypsum levels up to $3.01 \mathrm{tha}^{-1}$. In a study on the recovery of degraded Urochloa brizantha pastures, Sousa et al. (2001) found that adding only $200 \mathrm{~kg} \mathrm{ha}^{-1}$ of gypsum in a two-year experimental period caused dry matter yield to increase up to $50 \%$.

Considering the maximum accumulated dry matter as a function of gypsum application, we observed that, in the first year, there were $26,19,24$, and $37 \%$ increases for the first, second, third, and fourth harvests, respectively, in relation to the treatment with chemical fertilizer only. The greatest increase was found at the fourth harvest, which corresponds to the dry season (37\%). In most times, responses are only manifested in dry periods, and, in this case, the greater development of the plant can be attributed to the further deepening of roots in the soil, which were capable of absorbing deeper water. In the second year, the first, second, third, and fourth harvests had 25, 22, 21 , and $15 \%$ increase, respectively, amounting to a dry matter yield increase of up to $189 \%$ in both years, with the application of gypsum. In an experiment conducted on a Cerrado Red-Yellow Latosol with $26 \%$ clay, corrected with lime, and macro- and micronutrients, Sousa et al. (2001) evaluated the increase in Brachiaria grass (U. decumbens) dry matter comparing treatments done with and without gypsum. In three years, the dry matter had increased to up to $260 \%$. Similarly, pasture productivity decreased when gypsum was not applied, especially in the third year after establishment.

Cantarella and Montezano (2010) found that the action of gypsum applied in the subsoil allows an increase in the

Table 1 - Urochloa brizantha height in the treatments (1st, 2nd, and 3rd growth stages [rainy season] and 4th growth stage [dry season]) during the first and second cycles

\begin{tabular}{|c|c|c|c|c|c|c|c|c|}
\hline \multirow{3}{*}{ Treatment $^{1}$} & \multicolumn{4}{|c|}{ First cycle } & \multicolumn{4}{|c|}{ Second cycle } \\
\hline & \multicolumn{3}{|c|}{ Rainy } & \multirow[t]{2}{*}{ Dry } & \multicolumn{3}{|c|}{ Rainy } & \multirow[t]{2}{*}{ Dry } \\
\hline & \multicolumn{3}{|c|}{ Growth stage } & & \multicolumn{3}{|c|}{ Growth stage } & \\
\hline \multicolumn{9}{|c|}{$\mathrm{cm}$} \\
\hline 0 & 103.4 & 40.8 & 30.4 & 14.9 & 30.5 & 42.7 & 32.2 & 7.9 \\
\hline 450 & 119.0 & 43.6 & 29.9 & 15.2 & 30.0 & 40.0 & 33.5 & 9.8 \\
\hline 3600 & 112.9 & 44.0 & 27.4 & 15.7 & 31.7 & 49.7 & 31.0 & 9.3 \\
\hline $\mathrm{CF}$ & 71.3 & 30.0 & 18.9 & 12.2 & 21.2 & 27.0 & 15.7 & 7.7 \\
\hline $\mathrm{CV}(\%)$ & 8.84 & 3.23 & 6.87 & 7.65 & 6.40 & 11.62 & 8.82 & 7.21 \\
\hline Significance of regression analysis & $\mathrm{Q}<0.001$ & $\mathrm{Q}<0.05$ & $\mathrm{Q}<0.001$ & $\mathrm{Q}<0.05$ & ns & $\mathrm{Q}<0.05$ & $\mathrm{Q}<0.05$ & $\mathrm{Q}<0.001$ \\
\hline Unmanaged vs. others ${ }^{2}$ & $<0.001$ & $<0.001$ & $<0.001$ & $<0.001$ & $<0.001$ & $<0.001$ & $<0.001$ & $<0.001$ \\
\hline
\end{tabular}


use efficiency of other mobile nutrients, especially $\mathrm{N}_{-} \mathrm{NO}_{3}^{-}$, which may explain the increase in dry matter produced. The use of gypsum can also improve the recovery of nutrients with low mobility in the soil, such as P. The improved P absorption obtained with application of gypsum is justified by the more uniform water extraction in the soil profile, leaving the surface layer moist for a longer time (Sousa and Lobato, 2004). The lack of available water limits P absorption due to its lower diffusion coefficient in the soil.

The evaluation of contrasts showed a significant difference, in which the group of fertilized treatments provided larger dry matter accumulations than control treatment (Table 2). In addition to the lower dry matter yield from control treatment, this variable decreased by $21 \%$ from the first to the second cycle. The declines in dry matter yield in the subsequent years were due to the export of nutrients as well as depletion of soil reserves (Magalhães et al., 2002). As stated by Guelfi et al. (2013), the lack of replenishment of nutrients extracted by the forage plants over the years is one of the main factors responsible for the low sustainability rates of this ecosystem.

In the first evaluated cycle, the number of tillers was influenced by gypsum levels only in the second, third, and fourth growth stages $(\mathrm{P}<0.01)$ (Figure 4). Estimated gypsum levels of 1865,2455 , and $2212 \mathrm{~kg} \mathrm{ha}^{-1}$ provided the maximum numbers of 669,751 , and 731 tillers, respectively. During the first assessment, an average number of 543 tillers $\mathrm{m}^{-2}$ was found.

During the second cycle, the different gypsum levels influenced the number of tillers in all of the four evaluated

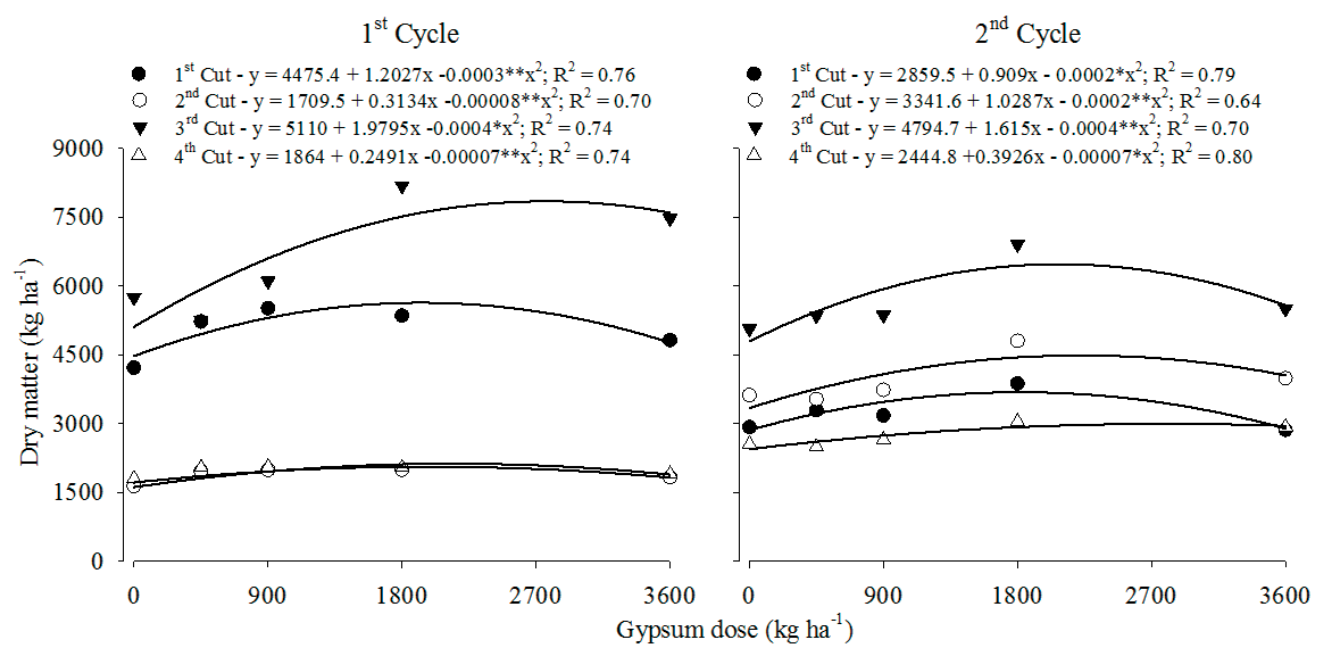

Figure 3 - Dry matter of Urochloa brizantha shoots subjected to levels of agricultural gypsum (1st, 2nd, and 3rd growth stages [rainy season] and 4th growth stage [dry season]) in the first and second cycles.

Table 2 - Dry matter of Urochloa brizantha shoots at the 1st, 2nd, 3rd (rainy season) and 4th growth stage (dry season) in two cycles under five gypsum rates

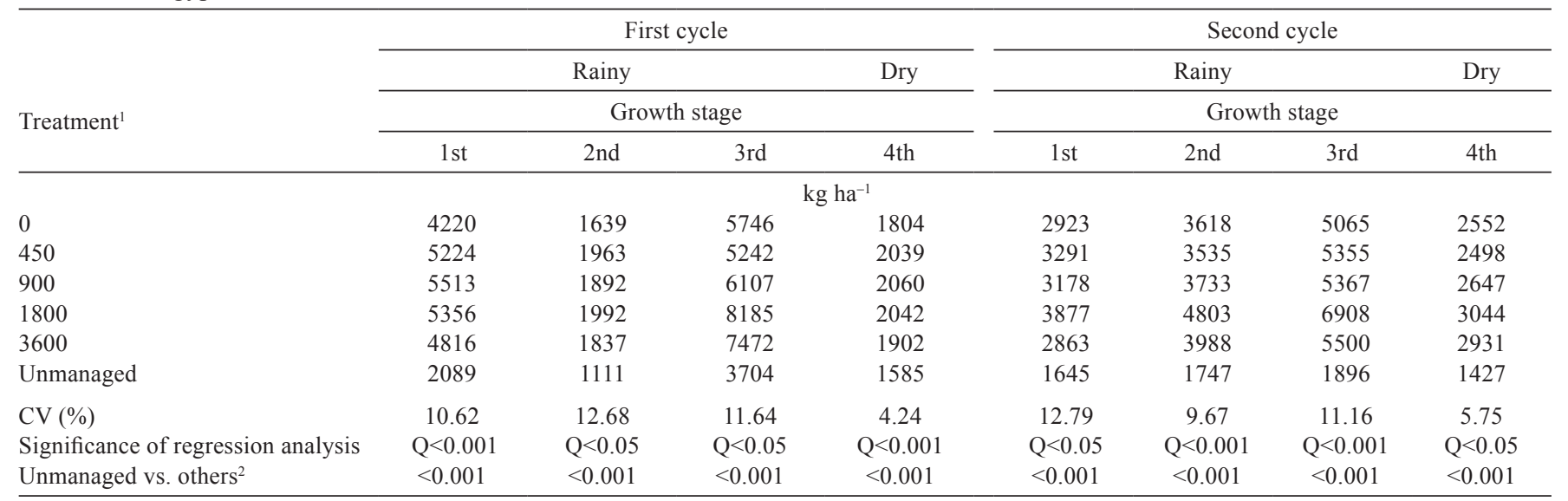

CV - coefficient of variation; Q - quadratic.

${ }_{1}^{1}$ Gypsum rates in $\mathrm{kg} \mathrm{ha}^{-1}$.

${ }^{2}$ Significance of the contrast between the unmanaged treatment with the other treatments. These contrasts indicate the effect of additional fertilizer application with $\mathrm{N}$, $\mathrm{P}$, and $\mathrm{K}$. 
seasons $(\mathrm{P}<0.01)$ (Figure 4). According to the adjusted model, the highest numbers of tillers $(728,731,821$, and 840) were obtained using the estimated gypsum levels of 2128, 1950, 1910, and $2012 \mathrm{~kg} \mathrm{ha}^{-1}$. Mesquita et al. (2004) studied the effect of levels of limestone, limestone + gypsum, and phosphorus on a $U$. decumbens intercropped with Stylosantes guianensis cv. Mineirão and found that the gypsum applications led to an increase in the number of tillers only in the second year of evaluation, reaching a maximum of 556 tillers $\mathrm{m}^{-2}$ with the gypsum level of $2820 \mathrm{~kg} \mathrm{ha}^{-1}$.

The contrast of means of the fertilized and control treatments showed no significant differences only in the first growth from the first evaluated cycle. In the other periods, the highest number of tillers was obtained when the forage plants were fertilized (Table 3). Many studies are available in the literature demonstrating the efficiency of fertilization in increasing the number of tillers in forage species (Moreira et al., 2009; Santos et al., 2007; Coutinho et al., 2014; Dias et al., 2015).

In the first evaluation cycle, there was an influence of gypsum levels on the development of the palisade grass root system in the two soil layers sampled $(\mathrm{P}<0.01)$. According to the fitted equation, the estimated gypsum level of $1469 \mathrm{~kg} \mathrm{ha}^{-1}$ yielded the maximum amount of roots. In the $0.20-0.40 \mathrm{~m}$ soil layer, $1207 \mathrm{~kg} \mathrm{ha}^{-1}$ gypsum provided greater development of the root systems. High gypsum rates provided a lower root system development in both $0.00-0.20$ and 0.20-0.40 m layers. The influence of gypsum levels in the second cycle was only observed in the $0.20-0.40 \mathrm{~m}$ layer

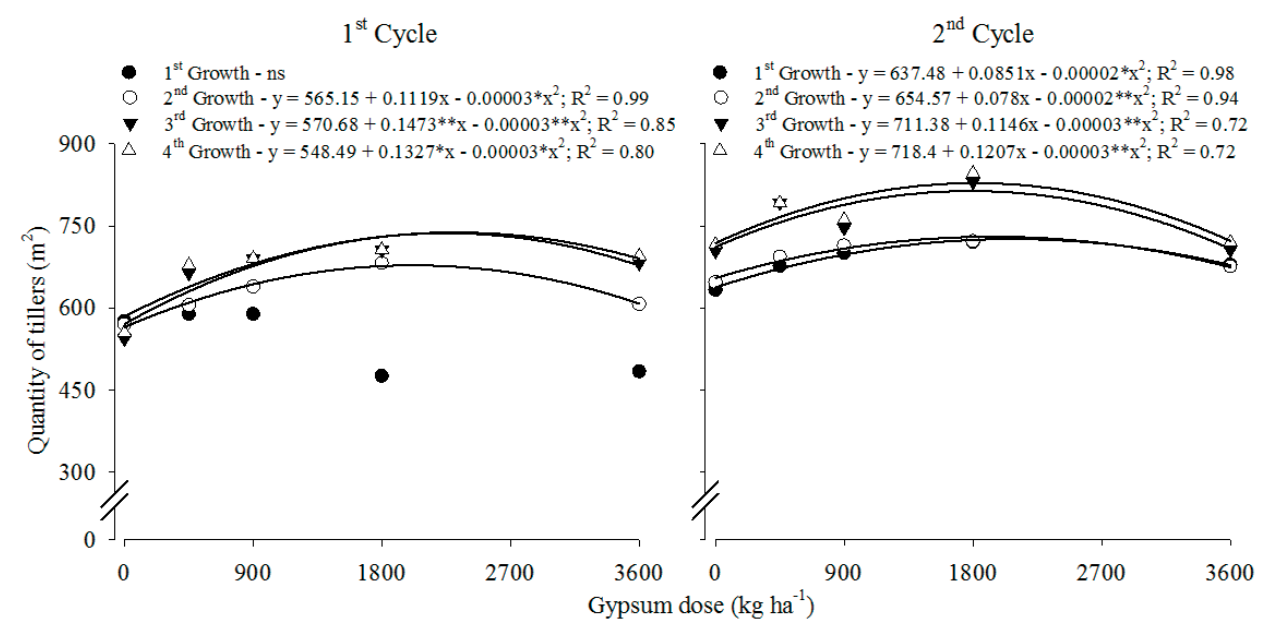

Figure 4 - Number of tillers per square meter of Urochloa brizantha subjected to levels of agricultural gypsum (1st, 2nd, and 3rd growth stages [rainy season] and 4th growth stage [dry season]) during the first and second cycles.

Table 3 - Number of tillers of Urochloa brizantha per square meter based on treatments [1st, 2nd, and 3rd growth stages (rainy season) and 4th growth stage (dry season)] during the first and second cycles

\begin{tabular}{|c|c|c|c|c|c|c|c|c|}
\hline \multirow{3}{*}{ Treatment $^{1}$} & \multicolumn{4}{|c|}{ First cycle } & \multicolumn{4}{|c|}{ Second cycle } \\
\hline & \multicolumn{3}{|c|}{ Rainy } & Dry & \multicolumn{3}{|c|}{ Rainy } & Dry \\
\hline & \multicolumn{4}{|c|}{ Growth stage } & \multicolumn{4}{|c|}{ Growth stage } \\
\hline \multicolumn{9}{|c|}{ tillers $\mathrm{m}^{-2}$} \\
\hline 0 & 576 & 570 & 544 & 555 & 633 & 647 & 704 & 716 \\
\hline 450 & 589 & 605 & 664 & 678 & 677 & 694 & 792 & 792 \\
\hline 3600 & 484 & 607 & 682 & 695 & 679 & 676 & 706 & 720 \\
\hline Unmanaged & 335 & 431 & 432 & 440 & 445 & 472 & 574 & 581 \\
\hline $\mathrm{CV}(\%)$ & 36.51 & 12.93 & 9.52 & 9.48 & 8.64 & 10.92 & 5.91 & 6.20 \\
\hline Significance of regression analysis & ns & $\mathrm{Q}<0.05$ & $\mathrm{Q}<0.001$ & $\mathrm{Q}<0.05$ & $\mathrm{Q}<0.05$ & $\mathrm{Q}<0.001$ & $\mathrm{Q}<0.001$ & $\mathrm{Q}<0.001$ \\
\hline Unmanaged vs. others ${ }^{2}$ & 0.058 & $<0.001$ & $<0.001$ & $<0.001$ & $<0.001$ & $<0.001$ & $<0.001$ & $<0.001$ \\
\hline
\end{tabular}

$\mathrm{CV}$ - coefficient of variation; Q - quadratic; ns - not significant.

${ }^{1}$ Gypsum rates in $\mathrm{kg} \mathrm{ha}^{-1}$.

${ }^{2}$ Significance of the contrast between the unmanaged treatment with the other treatments. These contrasts indicate the effect of additional fertilizer application with $\mathrm{N}$, P, and K. 
$(\mathrm{P}<0.01)$. According to the adjusted equation, the estimated gypsum level of $1687 \mathrm{~kg} \mathrm{ha}^{-1}$ provided the maximum root mass, $3763 \mathrm{~kg} \mathrm{ha}^{-1}$, which is $40 \%$ higher compared with the treatment that received chemical fertilizer only (Figure 5). The application of gypsum led to an increase in root volume due to the high calcium levels in the subsurface $(27 \%$ when the initial content was considered), thus allowing plants to have better tolerance to longer dry periods or dry spells and to more efficiently use the applied nutrients or those originally from the soil. Therefore, in this study, the penetration of the grass roots into a highly weathered Cerrado subsoil was more limited by calcium deficiency than by aluminum toxicity, since the presence of aluminum was not detected in the initial soil analysis. Calcium deficiency in the soil solution in the meristematic regions of roots may pose several restrictions to root development, since this nutrient is not internally redistributed in the plant.
Contrast analysis (Table 4) revealed that the group of fertilized treatments displayed a larger amount of root dry matter than control in the $0.00-0.20$ m layer in the first cycle and in both evaluated layers in the second cycle. This greater development of the root system is a result of the greater availability of nutrients, mainly $\mathrm{P}$, whose natural occurrence in the Cerrado region is low, besides the effect of $\mathrm{Ca}$ in deeper layers.

There were no changes in the studied chemical parameters of the soil $(\mathrm{pH}, \mathrm{H}+\mathrm{Al}$, cation-exchange capacity, and organic matter) in any of the evaluated cycles after the application of gypsum. Phosphorus contents were only influenced in the first year, in the $0.00-0.20 \mathrm{~m}$ layer $(\mathrm{P}<0.05)$, with a quadratic fit to the gypsum levels. According to the equation $\left(\hat{\mathrm{y}}=4.4908+0.0007 \mathrm{x}-0.0000001^{*} \mathrm{x}^{2} ; \mathrm{R}^{2}=0.69\right)$, the estimated rate of $3500 \mathrm{~kg} \mathrm{ha}^{-1}$ provided the maximum $\mathrm{P}$ content $\left(5.7 \mathrm{mg} \mathrm{dm}^{-3}\right)$. Gypsum, a by-product of phosphoric

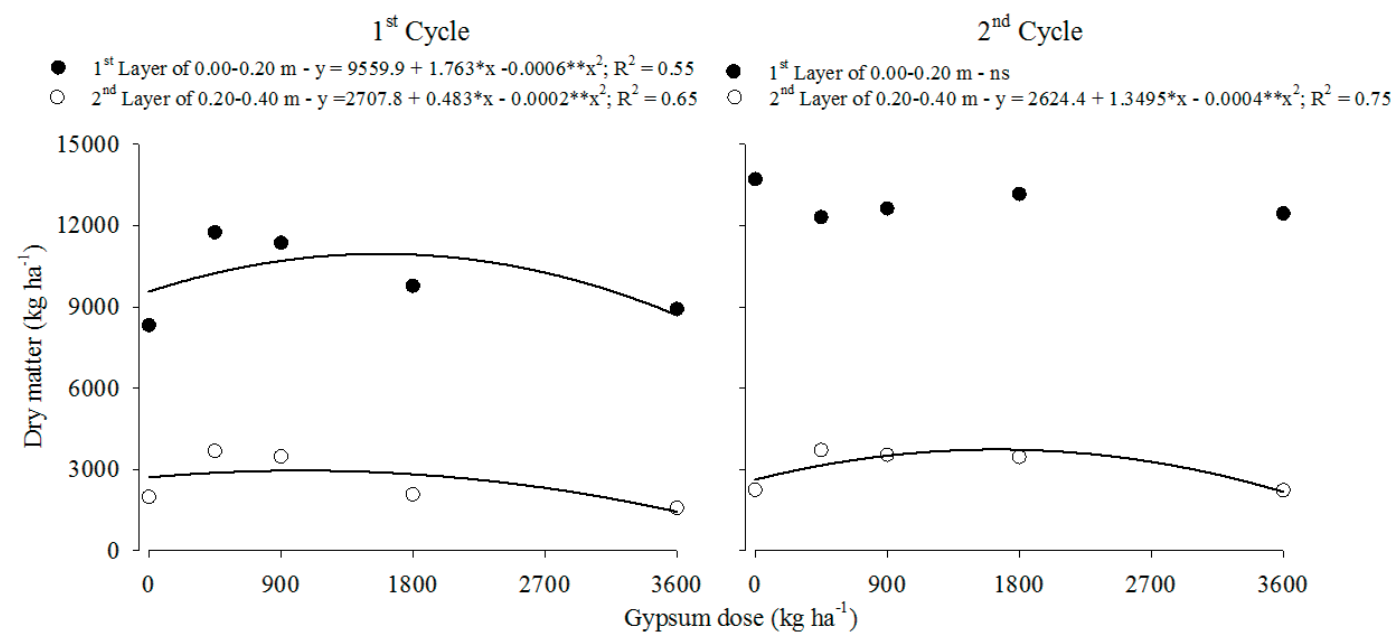

Figure 5 - Dry matter of Urochloa Brizantha roots in the presence of gypsum (0.00-0.20 and 0.20-0.40 m layers) for the first and second evaluation cycles.

Table 4 - Dry matter of Urochloa brizantha roots in the treatments (0.00-0.20 and 0.20-0.40 m layers) during the first and second evaluation cycles

\begin{tabular}{|c|c|c|c|c|}
\hline \multirow{2}{*}{ Treatment $^{1}$} & \multicolumn{2}{|c|}{ First cycle } & \multicolumn{2}{|c|}{ Second cycle } \\
\hline & $0.00-0.20 \mathrm{~m}$ & $0.20-0.40 \mathrm{~m}$ & $0.00-0.20 \mathrm{~m}$ & $0.20-0.40 \mathrm{~m}$ \\
\hline 0 & 8320 & 1985 & 13703 & 2247 \\
\hline 450 & 11750 & 3680 & 12305 & 3707 \\
\hline 900 & 11360 & 3475 & 12623 & 3538 \\
\hline Unmanaged & 8085 & 1955 & 9430 & 2008 \\
\hline $\mathrm{CV}(\%)$ & 10.76 & 32.02 & 11.40 & 8.56 \\
\hline Significance of regression analysis & $\mathrm{Q}<0.05$ & $\mathrm{Q}<0.05$ & ns & $\mathrm{Q}<0.001$ \\
\hline Unmanaged vs. others ${ }^{2}$ & $<0.001$ & 0.181 & $<0.001$ & $<0.001$ \\
\hline
\end{tabular}

CV - coefficient of variation; Q - quadratic; ns - not significant.

${ }^{1}$ Gypsum rates in $\mathrm{kg} \mathrm{ha}^{-1}$.

${ }^{2}$ Significance of the contrast between the unmanaged treatment with the other treatments. These contrasts indicate the effect of additional fertilizer application with $\mathrm{N}$, P, and $\mathrm{K}$. 
acid industry, contains mainly calcium sulfate and small concentrations of $\mathrm{P}$ and $\mathrm{F}$. The phosphorus contained in the gypsum, considered an impurity, can be important in plant nutrition if high levels of gypsum are applied (Caires et al., 2011) (Table 5).

For the $\mathrm{K}$ contents, there was fit only in the first cycle, in both evaluated layers $(\mathrm{P}<0.05)(\hat{\mathrm{y}}=0.622+$ $0.0003 x-0.00000009^{* *} x^{2} ; R^{2}=0.70$ and $\hat{y}=0.4297+$ $0.0003 \mathrm{x}-0.00000009^{* *} \mathrm{x}^{2} ; \mathrm{R}^{2}=0.99$ ), with maximum values obtained with the estimated gypsum rate of $1667 \mathrm{~kg} \mathrm{ha}^{-1}$. Although the application of gypsum influenced the vertical mobility of potassium (Serafim et al., 2012), according to the obtained data, we can assert that this effect did not result in significant leaching of this element.

The Ca contents were influenced by the application of the gypsum in the two layers sampled during the first cycle and in the $0.20-0.40 \mathrm{~m}$ soil layer in the second cycle $(\mathrm{P}<0.01)$. In the first cycle, according to the adjusted

Table 5 - Chemical analysis of soil in the treatments (0.00-0.20 and 0.20-0.40 m layers) during the first and second evaluation cycles

\begin{tabular}{|c|c|c|c|c|c|c|c|c|c|}
\hline \multirow{2}{*}{ Treatment $^{1}$} & $\mathrm{pH}$ & $\mathrm{OM}$ & $\mathrm{P}_{\text {resin }}$ & $\mathrm{H}+\mathrm{Al}$ & $\mathrm{K}$ & $\mathrm{Ca}$ & $\mathrm{Mg}$ & CEC & $\mathrm{S}$ \\
\hline & & $\mathrm{g} \mathrm{dm}^{-3}$ & $\mathrm{mg} \mathrm{dm}^{-3}$ & & --------------. & $-\mathrm{mmol}_{\mathrm{c}} \mathrm{dm}$ & --------- & & $\mathrm{mg} \mathrm{dm}^{-3}$ \\
\hline \multicolumn{10}{|c|}{ First cycle } \\
\hline \multicolumn{10}{|c|}{$0.00-0.20 \mathrm{~m}$ layer } \\
\hline 0 & 4.9 & 30 & 4.2 & 33 & 0.67 & 12 & 6.2 & 52 & 5.5 \\
\hline 450 & 4.9 & 31 & 5.2 & 30 & 0.62 & 15 & 6.0 & 52 & 8.7 \\
\hline 900 & 5.1 & 32 & 5.2 & 28 & 0.95 & 19 & 7.2 & 55 & 12.2 \\
\hline 1800 & 5.0 & 32 & 5.2 & 30 & 0.90 & 17 & 6.0 & 54 & 11.2 \\
\hline 3600 & 4.8 & 32 & 5.5 & 33 & 0.62 & 13 & 4.5 & 52 & 12.0 \\
\hline Unmanaged & 5.0 & 32 & 2.5 & 29 & 0.75 & 15 & 7.0 & 53 & 4.5 \\
\hline CV $(\%)$ & 1.82 & 12.74 & 29.79 & 7.63 & 13.31 & 10.17 & 19.71 & 14.83 & 14.12 \\
\hline Significance of regression analysis & ns & ns & $\mathrm{Q}<0.05$ & ns & $\mathrm{Q}<0.001$ & $\mathrm{Q}<0.001$ & $\mathrm{~L}<0.05$ & ns & $\mathrm{Q}<0.001$ \\
\hline Unmanaged vs. others ${ }^{2}$ & 0.176 & 0.789 & 0.004 & 0.276 & 0.929 & 0.773 & 0.154 & 0.626 & 0.001 \\
\hline \multicolumn{10}{|c|}{$0.20-0.40 \mathrm{~m}$ layer } \\
\hline 0 & 4.9 & 23 & 1.7 & 28 & 0.42 & 10 & 4.2 & 42 & 4.5 \\
\hline 450 & 5.1 & 22 & 2.7 & 26 & 0.57 & 13 & 5.0 & 44 & 15.5 \\
\hline 900 & 5.1 & 23 & 1.7 & 25 & 0.65 & 14 & 6.0 & 46 & 22.0 \\
\hline 1800 & 5.1 & 25 & 2.7 & 25 & 0.72 & 14 & 5.5 & 46 & 26.0 \\
\hline 3600 & 5.0 & 24 & 2.0 & 25 & 0.47 & 13 & 3.7 & 42 & 26.2 \\
\hline Unmanaged & 5.0 & 23 & 1.0 & 24 & 0.40 & 11 & 4.0 & 40 & 4.7 \\
\hline CV $(\%)$ & 1.77 & 14.91 & 34.96 & 6.21 & 25.45 & 17.61 & 24.51 & 8.79 & 25.38 \\
\hline Significance of regression analysis & ns & ns & ns & ns & $\mathrm{Q}<0.05$ & $\mathrm{Q}<0.001$ & $\mathrm{Q}<0.05$ & ns & $\mathrm{Q}<0.001$ \\
\hline Unmanaged vs. others ${ }^{2}$ & 0.763 & 0.740 & 0.007 & 0.156 & 0.002 & 0.228 & 0.179 & 0.08 & $<0.001$ \\
\hline
\end{tabular}

0

450

900

1800

3600

Unmanaged

CV (\%)

Significance of regression analysis

Unmanaged vs. others ${ }^{2}$

\section{0}

450

900

1800

3600

Unmanaged

CV (\%)

Significance of regression analysis

Unmanaged vs. others ${ }^{2}$

$\begin{array}{llll}4.9 & 26 & 6.5 & 37\end{array}$

\section{7}

4.8

4.8

5.0

4.8

3.92

ns

1.000

$$
28
$$

27

25

23

29

18.02

ns

0.291

4.9

4.8

4.9

4.9

5.0

4.8

3.91

ns

0.137

$\begin{array}{ll}6.5 & 37 \\ 7.7 & 39 \\ 6.5 & 39\end{array}$

$6.5 \quad 39$

$6.7 \quad 33$

$6.5 \quad 38$

$20.72 \quad 17.28$

ns ns

$0.700 \quad 0.605$

0.20-0.40 m layer

$\begin{array}{ll}5.7 & 35\end{array}$

$6.2 \quad 39$

$5.5 \quad 33$

$\begin{array}{ll}6.0 & 32\end{array}$

$\begin{array}{ll}5.2 & 31\end{array}$

6.2

40

18.45

29.69

21.20

0.472

0.255

\section{Second cycle}

0.00-0.20 m layer

$6.5 \quad 35$

1.4
1.5
1.3
1.2
1.2
1.4
18.51
$\mathrm{~ns}$
0.394

\section{5}

3.5

57

$59-10.2$

15

13

16

14

15

23.17

ns

0.736

3.5

3.0

3.2

3.5

4.0

28.27

ns

0.206

56

55

52

58

12.70

ns

0.369 $\mathrm{Q}<0.001$

1.30

2.12

1.22

1.22

1.02

\section{4}

16

16

16

17

1.35

33.93

$\begin{array}{ccc}4.2 & 58 & 8.2 \\ 4.5 & 62 & 7.5 \\ 3.2 & 54 & 10.2 \\ 3.0 & 52 & 9.7 \\ 3.5 & 51 & 12.7 \\ 4.2 & 62 & 7.5 \\ 20.57 & 15.61 & 17.42 \\ \mathrm{~ns} & \mathrm{~ns} & \mathrm{Q}<0.05 \\ 0.425 & 0.195 & 0.003\end{array}$

OM - organic matter; CEC - cation exchange capacity; CV - coefficient of variation; L - linear; Q - quadratic; ns - not significant.

${ }^{1}$ Gypsum rates in $\mathrm{kg} \mathrm{ha}^{-1}$.

${ }^{2}$ Significance of the contrast between the unmanaged treatment with the other treatments. These contrasts indicate the effect of additional fertilizer application with $\mathrm{N}$, $\mathrm{P}$, and $\mathrm{K}$. 
equations $\left(\hat{\mathrm{y}}=12.646+0.0064 \mathrm{x}-0.000002^{* *} \mathrm{x}^{2}, \mathrm{R}^{2}=0.80\right.$ and $\left.\hat{y}=10.911+0.0042 x-0.000001^{* *} x^{2}, R^{2}=0.87\right)$, gypsum levels of 1600 and $2100 \mathrm{~kg} \mathrm{ha}^{-1}$ resulted in the maximum $\mathrm{Ca}$ content in the $0.00-0.20$ and $0.20-0.40 \mathrm{~m}$ layers, respectively. Application of gypsum led to increased $\mathrm{Ca}$ contents in the deeper layer. In the $0.20-0.40 \mathrm{~m}$ deep layer, a maximum value of $15 \mathrm{mmol}_{\mathrm{c}} \mathrm{dm}^{-3}$ was observed, which is a $27 \%$ increase considering the initial content. In the second year, high Ca levels $\left(16 \mathrm{mmol}_{\mathrm{c}} \mathrm{dm}^{-3}\right)$ were also observed in the deeper layer, obtained with the estimated gypsum level of $2333 \mathrm{~kg} \mathrm{ha}^{-1}$, based on the following equation: $\hat{y}=13.331+0.0028 x-0.0000006^{*} x^{2}, R^{2}=0.66$. The use of gypsum is the main strategy to supply calcium in the subsurface in this already implemented pasture system.

For $\mathrm{Mg}$, there was an influence of gypsum levels only in the first cycle $(\mathrm{P}<0.05)$. In the soil layer of $0.00-0.20 \mathrm{~m}$ a decreasing linear fit occurred $\left(\hat{y}=6.6775-0.0005^{*} x ; R^{2}=0.76\right.$ ), meaning that higher levels of gypsum reduced the $\mathrm{Mg}$ levels. In the $0.20-0.40 \mathrm{~m}$ soil layer, a quadratic fit was observed $\left(\hat{y}=4.3385+0.0018 x-0.0000006^{*} x^{2} ; R^{2}=0.90\right)$, in which the gypsum level of $1500 \mathrm{~kg} \mathrm{ha}^{-1}$ resulted in the highest $\mathrm{Mg}$ content. These results indicate that there might have been greater $\mathrm{Mg}$ vertical mobility in the soil due to the high amount of $\mathrm{Ca}$ added with the higher gypsum levels. With cationic bases, $\mathrm{K}, \mathrm{Ca}$, and $\mathrm{Mg}$ displayed similar behavior in the soil, competing for the adsorption sites; however, $\mathrm{Ca}^{2+}$ has higher soil colloid adsorption energy as compared with $\mathrm{Mg}^{2+}$ and $\mathrm{K}^{+}$(Ramos et al., 2013). Serafim et al. (2012) also found that higher gypsum rates provided $\mathrm{Mg}$ leaching in the 0.00-0.20 m layer, but the decline of this nutrient did not mean total loss, since it accumulated in the deeper layers.

The application of gypsum levels influenced the $\mathrm{S}_{-} \mathrm{SO}_{4}{ }^{2-}$ content in the soil at both depths studied and the two cycles evaluated $(\mathrm{P}<0.01)\left(\hat{\mathrm{y}}=6.2846+0.0055 \mathrm{x}-0.000001^{* *} \mathrm{x}^{2}\right.$; $\mathrm{R}^{2}=0.81$ and $\hat{\mathrm{y}}=6.2077+0.0189 \mathrm{x}-0.000004^{* *} \mathrm{x}^{2} ; \mathrm{R}^{2}=$ 0.96 in the $0.00-0.20$ and $0.20-0.40 \mathrm{~m}$ layers in the first cycle; and $\hat{y}=8.5846+0.0036 x-0.0000007^{* *} x^{2} ; R^{2}=0.96$ and $\hat{y}=7.4846+0.0013 x-0.0000002^{* *} x^{2} ; R^{2}=0.57$ in the $0.00-0.20$ and $0.20-0.40 \mathrm{~m}$ layers in the second cycle). Note that there was proportional sulfate displacement as gypsum levels were increased, with maximum levels $\left(14 \mathrm{mg} \mathrm{dm}^{-3}\right.$ in the $0.00-0.20 \mathrm{~m}^{2}$ layer and $28 \mathrm{mg} \mathrm{dm}^{-3}$ in the $0.20-0.40 \mathrm{~m}$ layer with the estimated levels of 2750 and $2362 \mathrm{~kg} \mathrm{ha}^{-1}$ ) after five months of application. Mesquita et al. (2004) also found greater increases in the lower layer, due to the movement of $\mathrm{S}$ in form of accompanying anion. According to Caires et al. (2001), the improved sulfate content in the soil profile is of utmost importance to maintain productivity of grass crops, especially under drought conditions.
The application of the gypsum level of $3600 \mathrm{~kg} \mathrm{ha}^{-1}$ might have led to greater sulfate leaching into the deeper soil layers that were not evaluated. The speed at which sulfate moves is variable in different soils and should be slower in soils with higher clay contents. In the second year, the maximum contents (13 and $9 \mathrm{mg} \mathrm{dm}^{-3}$ ) were obtained with the estimated gypsum levels of 2751 and $3250 \mathrm{~kg} \mathrm{ha}^{-1}$ for the $0.00-0.20$ and $0.20-0.40 \mathrm{~m}$ deep layers, respectively.

The contrast between the means obtained in control treatment and the fertilized group was significant for the $\mathrm{P}$ contents in both evaluated layers in the first cycle; for $\mathrm{Ca}$ in the 0.20-0.40 m layer, in the second cycle; and for $\mathrm{S}_{-} \mathrm{SO}_{4}{ }^{2-}$ in both layers in the first cycle and in the $0.20-0.40 \mathrm{~m}$ layer, in the second cycle. For the other traits, there was no difference between control and fertilized treatments. The treatments that received fertilization displayed the highest $\mathrm{P}, \mathrm{Ca}$, and $\mathrm{S}^{-\mathrm{SO}_{4}}{ }^{2-}$ contents in the soil. In addition to fertilization, the treatments from this group received gypsum, whose composition includes these three nutrients.

\section{Conclusions}

Gypsum provides improvements in the chemical characteristics of the soil and thus greater development of both the shoot and the root system of palisade grass (Urochloa brizantha).

Gypsum application in the range of 1779 to $2886 \mathrm{~kg} \mathrm{ha}^{-1}$ plus chemical fertilization provides greater yields as compared with the use of chemical fertilizers only.

High levels of gypsum compromise the development of the palisade grass root system, especially in the $0.20-0.40 \mathrm{~m}$ soil layer.

\section{References}

Belchior, E. B.; Sousa, T. C. R.; Moreira, J. M. M. A. P.; Aguiar, J. L. P. and Teixeira, L. P. 2010. Avaliação dos impactos do uso do gesso agrícola na cultura da soja em algumas áreas do cerrado. Embrapa Cerrados, Planaltina.

Bonfim-Silva, E. M. and Monteiro, F. A. 2010. Nitrogênio e enxofre na adubação e em folhas diagnósticas e raízes do capim braquiária em degradação. Revista Brasileira de Zootecnia 39:641-1649.

Caires, E. F.; Feldhaus, I. C. and Blum, J. 2001. Crescimento radicular e nutrição da cevada em função da calagem e aplicação de gesso. Bragantia 60:213-223.

Caires, E. F.; Maschietto, E. H.; Garbuio, F. J.; Churka, S. and Joris, H. A. W. 2011. Surface application of gypsum in low acidic Oxisol under no-till cropping system. Scientia Agricola 68:209-216.

Cantarella, H. and Montezano, Z. F. 2010. Nitrogênio e enxofre. p.1-65. In: Boas práticas para uso eficiente de fertilizantes: Nutrientes. Prochnow, L. I.; Casarin, V. and Stipp, S. R., eds. IPNI, Piracicaba. 
Crusciol, C. A. C.; Costa, C. H. M.; Castro, G. S. A. and Volf, M. R. 2016. Manejo adequado da fertilidade do solo para uma agricultura sustentável no Cerrado: Avanços e desafios. p.17-48. In: Práticas de manejo do solo para adequada nutrição de plantas no Cerrado. Flores, R. A. and Cunha, P. P., eds. Gráfica UFG, Goiás.

Coutinho, E. L. M.; Franco, H. C. J.; Orioli Junior, V.; Pasquetto, J. V. G. and Pereira, L. S. 2014. Calagem e adubação potássica para o capim-tifton 85. Biosciense Journal 30:101-111.

Custódio, D. P.; Oliveira, I. P.; Costa, K. A. P.; Santos, R. S. M. and Faria, C. D. 2005. Avaliação do gesso no desenvolvimento e produção do capim-tanzânia. Ciência Animal Brasileira 6:27-34.

Dias, D. G.; Pegoraro, R. F.; Alves, D. D., Porto, E. M. V.; Santos Neto, J. A. and Aspiazú, I. 2015. Produção do capim Piatã submetido a diferentes fontes de fósforo. Revista Basileira de Engenharia Agrícola e Ambiental 19:330-335.

Embrapa - Empresa Brasileira de Pesquisa Agropecuária. 2013. Sistema brasileiro de classificação de solos. 3.ed. Embrapa, Brasília.

Guelfi, D. R.; Faquin, V.; Souza, M. A. S.; Oliveira, G. C.; Santoucy, S. G. and Bastos, C. E. A. 2013. Características estruturais e produtivas do capim-marandu sob efeitos de corretivos da acidez, gesso e compactação do solo. Interciencia 38:681-687.

Magalhães, R. T.; Oliveira, I. P. and Kliemann, H. J. 2002. Relações da produção de massa seca e as quantidades de nutrientes exportados por Brachiaria brizantha em solos sob sistema "Barreirão". Pesquisa Agropecuária Tropical 32:13-20.

Mesquita, E. E.; Fonseca, D. M.; Pinto, J. C.; Nascimento Junior, D.; Pereira, O. G.; Venegas, V. H. A. and Moreira, L. M. 2004. Estabelecimento de pastagem consorciada com aplicação de calcário, fósforo e gesso. Ciência e Agrotecnologia 28:428-436.

Monteiro, F. A. 2010. Pastagens. p.233-285. In: Boas práticas para uso eficiente de fertilizantes. Prochnow, L. I.; Casarin, V. and Stipp, S. R., eds. IPNI, Piracicaba.

Moreira, L. M.; Martuscello, J. A.; Fonseca, D. M.; Mistura, C.; Morais, R. V. and Ribeiro Júnior, J. I. 2009. Perfilhamento, acúmulo de forragem e composição bromatológica do capim-braquiária adubado com nitrogênio. Revista Brasileira de Zootecnia 38:1675-1684.

Muller, M. M. L.; Guimarães, M. D. E. F.; Desjardins, T. and Silva, M. P. F. 2001. Degradação de pastagens na Região Amazônica: propriedades físicas do solo e crescimento de raízes. Pesquisa Agropecuária Brasileira 36:409-1418.

Oliveira, I. P.; Costa, K. A. P.; Faquin, V.; Maciel, G. A.; Neves, B. P. and Machado, E. L. 2009. Efeitos de fontes de cálcio no desenvolvimento de gramíneas solteiras e consorciadas. Ciência e Agrotecnologia 33:592-598.

Peron, A. J. and Evangelista, A. R. 2004. Degradação de pastagens em regiões de cerrado. Ciência e Agrotecnologia 28:655-661.
Pimenta, L. L. M.; Zonta, E.; Brasil, F. C.; Anjos, L. H. C.; Pereira, M. G. and Stafanato, J. B. 2010. Fertilidade do solo em pastagens cultivadas sob diferentes manejos, no noroeste do Rio de Janeiro. Revista Brasileira de Engenharia Agrícola e Ambiental 14:1136-1142.

Raij, B. Van; Andrade, J. C.; Cantarella, H. and Quaggio, J. A. 2001. Análises químicas para avaliação da fertilidade de solos tropicais. IAC; FUNDAG, Campinas.

Ramos, B. Z,; Toledo, J. P. V. F.; Lima, J. M.; Serafim, M. E.; Bastos, A. R. R.; Guimarães, P. T. G. and Coscione, A. R. 2013. Doses de gesso em cafeeiro: influência nos teores de cálcio, magnésio, potássio e pH na solução de um Latossolo Vermelho distrófico. Revista Brasileira de Ciência do Solo 37:1018-1026.

Rodrigues, R. C.; Mattos, H. B.; Pereira, W. L. M.; Andreotti, N. F. and Santos, A. L. 2004. Perfilhamento do capim-braquiária cultivado em solo proveniente de uma pastagem degradada em função de doses de enxofre, nitrogênio e calcário. Boletim de Indústria Animal 61:39-47.

Santos, A. S.; Santana, C. V. S.; Mistura, C. and Lopes, R. S. 2007. Efeito da adubação nitrogenada e potássica na dinâmica, peso e número de perfilho do capim-aruana. Agropecuária Científica no Semi-Árido 3:18-22.

Serafim, M. E.; Lima, J. M.; Lima, V. M. P.; Zeviani, W. M. and Pessoni, P. T. 2012. Alterações físico-químicas e movimentação de íons em Latossolo gibbsítico sob doses de gesso. Bragantia 71:75-81.

Soratto, R. P. and Crusciol, C. A. C. 2008. Produção de fitomassa e acúmulo de nutrientes pela aveia-preta em função da aplicação de calcário e gesso em superfície na implantação do sistema plantio direto. Ciência Rural 38:928-935.

Sousa, D. M. G.; Vilela, L.; Lobato, E. and Soares, W. V. 2001. Uso de gesso, calcário e adubos para pastagem no Cerrado. Embrapa CPAC, Planaltina.

Sousa, D. M. G. and Lobato, E. 2004. Correção da acidez do solo. p.81-96. In: Cerrado: correção do solo e adubação. Sousa, D. M. G. and Lobato, E., eds. Embrapa Cerrados, Planaltina.

Vilela, L.; Soares, W. V.; Sousa, D. M. G. and Macedo, M. C. M. 2004. Calagem e adubação para pastagens. p.367-382. In: Cerrado: correção do solo e adubação. Sousa, D. M. G. and Lobato, E., eds. Embrapa Cerrados, Planaltina.

Vitti, C. G.; Luz, P. H. C.; Malavolta, E.; Dias, A. S. and Serrano, C. G. E. 2008. Uso do gesso em sistemas de produção agrícola. GAPE, Piracicaba.

WRB - World Reference Base. 2015. World Reference Base for Soil Resoures 2014, update 2015. Internacional soil classification system for naming soils and creating legends for soil maps. Word Soil Resources Reports No. 106. FAO, Rome. 